\title{
The Design of a Theme-Based and Genre-Oriented Strategic Reading Course to Improve Students' Reading Comprehension Skills at a Public School in Colombia
}

\author{
Diseño de un curso de estrategias de lectura orientado \\ por la instrucción basada en contenidos y el enfoque de géneros \\ para el mejoramiento de las habilidades de comprensión lectora \\ de los estudiantes de un colegio público en Colombia*
}

\author{
Fabián Padilla De La Cerda \\ fdelacerda@uninorte.edu.co \\ Universidad del Norte, Barranquilla, Colombia
}

This paper reports the process of designing and partially implementing and evaluating a content-based and genre-oriented syllabus with a group of ninth graders at a public school in Barranquilla, Colombia. The syllabus sought to promote reading strategies in order to improve learners' comprehension of natural science texts. The results of this intervention show that the use of academic texts with low achievers, who in turn can develop a good comprehension of different kind of texts, is possible if these students are aware of the structure of the texts they are reading and if they are provided with reading strategies that are appropriate for each genre.

Key words: Content-based instruction, genre approach, reading comprehension, reading strategies, syllabus design.

* Received: July 20, 2015. Accepted: February 21, 2016.

How to cite this article (APA 6th ed.):

Padilla De La Cerda, F. (2016). The design of a theme-based and genre-oriented strategic reading course to improve students' reading comprehension skills at a public school in Colombia. HOW, 23(1), 49-67. http://dx.doi.org/10.19183/how.23.1.143.

This article is licensed under a Creative Commons Attribution-NonCommercial-NoDerivatives 4.0 International License. License Deed can be consulted at http://creativecommons.org/licenses/by-nc-nd/4.0/. 
Este proyecto muestra el proceso de diseño y la parcial implementación y evaluación de un programa basado en contenidos y géneros textuales con estudiantes de noveno grado de una escuela pública de Barranquilla, Colombia. El plan de estudio tenía como objetivo promover estrategias de lectura para mejorar la comprensión de textos de Ciencias Naturales. Los resultados de esta intervención muestran que es posible utilizar textos académicos con estudiantes de nivel principiante, los cuales pueden alcanzar una muy buena comprensión de diversos tipos de textos, si se les da a conocer la estructura del texto utilizado y se les provee con estrategias de lectura que sean acordes con el género textual.

Palabras clave: comprensión de lectura, diseño de programa, enfoque de géneros, estrategias de lectura, instrucción basada en contenidos.

\section{Introduction}

The educational system in Colombia is divided into two main sectors: private and public. On the one hand, private schools are usually well-structured in terms of locations, materials, and resources. On the other hand, most public schools have a series of lacks and necessities which make them vulnerable when they are compared to private institutions. In fact, this disparity is also found in the field of English teaching since students from private schools often have a good level of English while students from public schools barely get to know the basics after finishing high school. This can be reflected in the results of the SABER test, the national standardized examination for students finishing secondary school, where lots of public school students reach A2, the level expected for primary students according to the Common European Framework of Reference (CEFR).

With the purpose of increasing the level of English among the students of the public sector, the Ministerio de Educacion Nacional (MEN, National Ministry of Education) has implemented the Programa Nacional de Bilingïismo (PNB, National Bilingual Program), which states that Colombian students should have a high level of English and be competent in the four skills of this language by the year 2019. The students of the public school where this study was carried out also faced problems when using English, especially when taking either institutional or standardized tests such as the SABER, which is basically based on reading competence. In turn, since reading represents one of the most essential means to acquire knowledge and reading comprehension is one of the most common problems students face in secondary school, I decided to implement a research project in order to help students enhance their reading comprehension skills. The following research question guided this inquiry: How does a reading class, focused on a theme-based and genre-oriented syllabus, develop students' reading comprehension skills?

This article describes the process of designing, partially implementing, and evaluating a content-based and genre-oriented syllabus that promotes reading strategies to improve learners' reading comprehension of natural science texts. For this intervention, a needs 
The Design of a Theme-Based and Genre-Oriented Strategic Reading Course to Improve Students' Reading Comprehension Skills at a Public School in Colombia

analysis was carried out in several steps to identify initially general needs and later, more specific wants and lacks of the target students regarding the reading skills and the content areas. Data were collected through classroom observations, a reading comprehension test, and a think-aloud protocol. The decision for the selection of the content was supported by an analysis of the school programs, as well as surveys about students' preferences, interviews, and observations of content teachers' classes. As a result, a four-unit syllabus focused on natural science topics was designed for ninth graders at a public school located in Barranquilla, Colombia.

\section{Theoretical Considerations}

The implementation of this project was founded on the conception of reading as a social, interactive, and dynamic process; as Alderson (2000) indicates, reading is a process in which the reader interacts with a text. During the development of this interaction the reader not only deciphers the text, gives meaning to every word, or gives meaning to the whole text, but also thinks about what he or she is reading, relates this new meaning to what he or she previously knew or read (schemata), and predicts what he or she expects to come. Wallace (1992) argues reading represents a dynamic relationship (interaction) among the writer, the reader, and the text itself. She conceives reading as a "social, critical and interpretative process" (p. 4). For her, reading is predominantly social in "the sense that readers and writers enact their roles as members of communities" (p. 9). Therefore, considering that reading is conceived as a social and active process, this intervention was based on socially-oriented approaches to learning and language.

\section{Vygotsky's Sociocultural Theory}

According to Vygotsky (1978), learning takes place when children interact with other people and through their cooperation with others (interpersonal plane). Moreover, when children interact, they also internalize models or patterns which are then individualized and become independent accomplishments. Likewise, this theory suggests that human higher mental functions such as rational thoughts and learning originate in social activities which take place on planes that are external to the individual; for example, the social, the historical, or the institutional planes (Johnson, 2003). The sociocultural theory was essential for this project since, as Lee (2010) states, reading "is a social interactional process requiring active construction of meaning among readers" (p. 226). This means that reading is not a process enclosed inside the brain, but rather an ability that human beings can develop with others.

\section{Genre and Genre-Based Approach}

As any other approach to teaching, a genre approach looks for the best way to help students learn a foreign language. This approach is basically supported on different principles 
whose main pillar is the text. Considering that students will perform in real contexts outside the school, the genre approach suits perfectly those teachers who think of their students as active members of academic, occupational, or social contexts or communities in which they have to be able to read, write, or speak (Hyland, 2007). The concept of genre first appeared with Bakhtin (1973) and his theory of dialogue or dialogic principles. In this theory, the author conceives genres as the ways individuals conceptualize the world and as the means they use to refer to reality.

On the other hand, Derewianka (1991) explores the concept of genre and describes six different kinds of genres and their respective purposes. First of all narratives, which tell stories to entertain readers; second, recounts that reconstruct past experiences by retelling events in original sequences; in other words, to tell what happened. Third, instructions or procedures that show how processes and events are achieved or how something is done. In the fourth place, explanations, which tell how or why something works or happens. In the fifth place, Derewianka mentions reports. The main objective of reports is to present factual information about a class of things and their characteristics. The last type of genre is represented by arguments and expositions which provide reasons for a state of affairs or a judgment. All these kinds of genres are found everywhere in different mediums such as letters, e-mails, messages, textbooks, newspapers, recipes, manuals, songs, novels, advertisements, menus, lectures, speeches, and all kind of discourses that have to be read and understood by students inside and outside the classroom.

The genre approach was suitable for this project because it provided a useful way to organize a reading program that suited the students' needs in terms of texts and activities which were meaningful for them. Being able to identify the structure of a text prompts a way to read it and to be more successful at understanding and learning from it. Considering this intervention was based on reading, the use of different kinds of written texts was pivotal to get students familiarized with their structures and facilitate their comprehensibility.

\section{Content-Based Instruction}

In education, content-based instruction (CBI) represents the integration of specific content with language teaching objectives. Other definitions of this approach are given by Brinton, Snow, and Wesche (1989), who state CBI is an approach that "integrates language instruction with content instruction, but which allows the content to determine the nature and order of the linguistic syllabus" (p. 2). Some writers believe the objective of CBI is to learn content while others think that content is just an excuse to facilitate learning a language, which is its real objective. Other authors such as Dueñas (2004) prefer a balanced approach and offer the same status to both language and content. 
The Design of a Theme-Based and Genre-Oriented Strategic Reading Course to Improve Students' Reading Comprehension Skills at a Public School in Colombia

There are several reasons why this approach was appropriate for the development of this intervention. First, CBI prompts reading texts as the main resources for giving input to students. Authentic texts were used to present information to the learners who used materials that were produced for native speakers. Furthermore, due to the fact the target school is trying to become a bilingual school as a long term goal, CBI was then a perfect approach serving as a reference or starting point.

\section{Reading Strategies}

When readers read a text, they employ different techniques that facilitate their comprehension. These techniques are known as strategies. Chamot (1987) says learning strategies are "techniques, approach or deliberate actions that students take in order to facilitate the learning, recall of both linguistic and content area information" (p. 71). Additionally, Oxford (1989) thinks learning strategies are "behaviors or actions that learners use to make language learning more successful, self- directed and enjoyable" (p. 154). Reading strategies are used by readers in order to understand better a text and as a response to internal or external factors that influence their choice.

A reading strategy is usually a plan that is selected intentionally by an individual in order to construct and provide meaning to a text. Learners use strategies before, during, and after reading. According to this procedure, strategies can also be classified as before, during, and after reading strategies (Preszler, 2005). Before reading strategies are used by readers and also by reading teachers with their students in order to activate their prior knowledge and to increase the reader's involvement in both the text and the learning process. During reading strategies are those that help readers to keep track of the text, make progress in the reading process and maintain comprehension as they read. After reading strategies are also called interactive strategies since most of the time they require students to share ideas and interact with others (Preszler, 2005).

\section{Context and Participants}

For the purpose of this project, 35 students of ninth grade were intervened. The intervention took place at a public school located in the southwestern part of Barranquilla, Colombia. This institution has students from different social classes, but $90 \%$ of them belong to socioeconomic strata 1,2, and 3 (just below middle class). The school is deeply committed to the goals of the PNB to raise the level of communicative competence in English by 2019. To accomplish this purpose, students are divided into levels of performance and learning. After taking a placement exam at the beginning of the school year, all the students of the same grade during English classes are separated and classified into three levels. Level 1 has the students with the lowest knowledge of English, and Level 3 the ones with the highest. 
Moreover, students receive English classes with the help of computers and technical resources. Additionally, and as a consequence of the introduction of the bilingualism project in the institution, in 2012 students started studying eight hours of English per week.

Regarding the English teachers, the staff consists of 14 members; all of them have a bachelor degree in Modern Languages; three of them have already finished a postgraduate course in Curriculum Design and five of them have obtained diplomas at a local languages institute. In turn, the teacher researcher who is conducting this intervention holds a master degree in the Teaching of English. Another means of linguistic and methodology improvement for teachers is the presence of native English speaker volunteers from both governmental and international organizations.

On the other hand, the school PEI (Proyecto Educativo Institucional [Institution's Educational Project]) has set out as its visional plan for 2014 to become a leader in the fields of labor competences, technology, commerce, and English skills in order to help students to be successful in both the academic field and job market. The mission of the school is to produce competent and competitive students with a defined life project oriented to be successful in this global world. With regard to the English program, students had always followed a series of books classified according to the CEFR; however, these books did not provide students with authentic input and the texts were not meaningful.

Consequently, in 2010 reading skill became an object of study that began to gain importance among English teachers, but there was little intervention to overcome students' reading comprehension difficulties. It was not until the implementation of the present study at the end of 2012 that the school began to take actions in order to give reading a relevant status and help students reach higher levels of L2 reading comprehension.

\section{Data Collection Procedure}

The data collection process of this intervention had two moments: One moment was the needs analysis and the other moment was related to the design, implementation, and evaluation of the content-based genre oriented reading course.

\section{The Needs Analysis}

For the needs analysis the instruments applied were a questionnaire for students, interviews of teachers and coordinator, and class observations. The questionnaire consisted of twenty-one questions about the students' expectations and beliefs toward the English learning process, their necessities and interests related to their reading skills, and their reading strategy use. The interviews of English teachers and coordinator showed the general concern regarding the students' low level of comprehension and how this was related to their low 
The Design of a Theme-Based and Genre-Oriented Strategic Reading Course to Improve Students' Reading Comprehension Skills at a Public School in Colombia

results on the national SABER test and other external examinations. The observation demonstrated students were satisfied neither with the methodology employed to teach reading nor with the activities or texts teachers used to develop their reading comprehension.

Once the needs analysis demonstrated students needed an intervention to enhance their reading comprehension, some other instruments were applied to confirm these results and to take the most appropriate decisions regarding the course design. These instruments were a reading proficiency test, a think aloud protocol, a content teachers class observation, and a student's survey on content.

\section{Reading Proficiency Test}

It was designed to assess the target group's level of proficiency in reading comprehension. The test consisted of ten questions; six of them evaluated the literal level while four evaluated the inferential one (see Appendix 1). The students were given a SABER type text related to Science in which they had to read three short texts to complete the exam. Thirty-five students took the examination and were warned that it was not a regular exam in order to reduce their anxiety. Results showed students had serious reading comprehension problems, probably for their lack of use of reading strategies; therefore, a think-aloud protocol was applied.

\section{Think-Aloud Protocol}

This instrument allowed the observer to see first-hand the process of task completion (Lewis, 1982). It was appropriate for this project because it let me observe my students' use of reading strategies while reading a text in English. For this technique, three students were selected; a low, an average, and a high-performance student. They read the same text for determining their level of reading proficiency and were asked a series of questions that were prepared beforehand. These questions were asked while students were reading the text to infer some of their reading processes (see Appendix 2). The think-aloud protocol showed they all employed strategies such as using images in the text for predicting what the text was about and for confirming the information they were reading, as well as the use of titles and the subtitles to preview content (see Table 1).

This instrument demonstrated some differences among the three students. The student with the highest score on the exam seemed to be the most strategic while reading. The intermediate student expressed his background knowledge and his knowledge of English usually helps him when reading in the target language. Meanwhile, the student with the lowest level did not use many strategies for the comprehension of the passage. This was the only student that used the knowledge of his mother tongue as a strategy to understand the vocabulary or the meaning of words. 
Table 1. The Think-Aloud Protocol

\begin{tabular}{|c|c|c|}
\hline Advanced & Intermediate & Beginner \\
\hline $\begin{array}{l}\text { Interviewer: What was the first } \\
\text { thing you did when you started } \\
\text { reading the text? } \\
\text { Student: Text words started } \\
\text { rolling in my mind, and then it } \\
\text { began like when a video is } \\
\text { playing. } \\
\text { I: And then what did you do } \\
\text { to understand the text? } \\
\text { S: The first thing I did as I } \\
\text { listened to that tape was } \\
\text { playing back images in my } \\
\text { head. For instance, bears live } \\
\text { in Africa so I imagine a bear, } \\
\text { the map of Africa and African } \\
\text { people and landscape. } \\
\text { I: And what else helps you } \\
\text { understand the text? } \\
\text { S: Connectors, connectors } \\
\text { help me. } \\
\text { I: Did you find any? } \\
\text { S: Yes and they help me } \\
\text { organize. } \\
\text { I: Why did you look up? What } \\
\text { did you do there? } \\
\text { S: Because the title of the text } \\
\text { often tells me the main idea of } \\
\text { the text or the paragraph. ... } \\
\text { There is a question: if I know } \\
\text { the difference between frog, } \\
\text { which is "rana" in Spanish, } \\
\text { and toad, which meaning I } \\
\text { don't know. As I'm not sure, I } \\
\text { decided to look at the title } \\
\text { again. }\end{array}$ & $\begin{array}{l}\text { Interviewer: What was the first } \\
\text { thing you did when you start } \\
\text { reading the text? } \\
\text { Student: I looked at the } \\
\text { images. } \\
\text { I: And after that, what else did } \\
\text { you do? } \\
\text { S: I started reading the text. } \\
\text { I: Immediately? } \\
\text { S: Yes. } \\
\text { I: Before starting reading the } \\
\text { text, didn't you read the title? } \\
\text { S: No, I always start reading } \\
\text { the text. } \\
\text { I: And why didn't you see it? } \\
\text { S: Because I go immediately to } \\
\text { the text, so I find out what it is } \\
\text { about. } \\
\text { I: OK, go ahead. } \\
\text { ‥ } \\
\text { I: How do you get to know } \\
\text { what the text is about? } \\
\text { S: By reading the text. I go } \\
\text { through it and that makes me } \\
\text { know about it. } \\
\text { I: What else helps you to know } \\
\text { what the text is about? } \\
\text { S: What I have learned in } \\
\text { English class. } \\
\text { I: OK. Go ahead. }\end{array}$ & $\begin{array}{l}\text { Interviewer: Yes, but what do } \\
\text { you do when you read? } \\
\text { Student: I try to identify the } \\
\text { words. } \\
\text { I: And what do you do to } \\
\text { identify them? } \\
\text { S: First of all, I don't } \\
\text { understand them. Well, there } \\
\text { are some I don't but some I } \\
\text { do understand. } \\
\text { I: And what do you do to } \\
\text { understand the ones you do } \\
\text { not know? } \\
\text { S: Well...there are some that } \\
\text { look like Spanish but not all of } \\
\text { them. There are others I do } \\
\text { know, though. } \\
\text { I: What did you do to get the } \\
\text { gist? } \\
\text { S: Well..first by the image, } \\
\text { second because I see the text } \\
\text { is about different animals. } \\
\text { I: What else helped you } \\
\text { understand the text? } \\
\text { S: The words that are...that are } \\
\text { not...that is the words I know } \\
\text { in Spanish. }\end{array}$ \\
\hline
\end{tabular}


The Design of a Theme-Based and Genre-Oriented Strategic Reading Course to Improve Students' Reading Comprehension Skills at a Public School in Colombia

\section{Survey on Content}

The survey was applied to select the topics of the reading texts for the design of a content-based course. It was designed as a checklist for students to choose their favorite. The topics were selected from the syllabus of the other school subjects such as science, social studies, arts, and ethics. Students chose the topics of science, social studies, and arts as the ones they preferred the most; therefore, the content class observations were addressed to these subjects. For science, the topic that ranked the most was the animal kingdom as well as the Solar System and the great contributors to social studies and famous artists.

\section{Content Class Observations}

The observations were focused on the methodology content teachers used to teach their subjects in Spanish. Of the three content subjects students selected, they seemed to participate, like, and be more interested in science. This was one of the reasons why I took the decision to implement a reading course in science. On the other hand, the data gathered strongly pointed to the need to improve students' reading skills through contextualized reading activities without neglecting the development of the other skills.

\section{The Pedagogical Proposal}

\section{Approaches to Course Design}

The proposed course embraces a hermeneutic approach to education because this endorses autonomy, construction of knowledge, and human development as its main features, and students are free to construct their own knowledge according to their reality. This selection is supported by the fact that it is essential for students to develop critical thinking and autonomy in the use of reading strategies. Concerning the approach to learning, this course design is framed within the sociocultural approach, represented by Vygotsky (1978), which places emphasis on the acquisition of knowledge through the interaction of the participants (Johnson, 2003). Regarding the approach to language, this course has a functional orientation of the language and conceives it as a social system of symbols immersed in a real context. As defined in systemic functional linguistics (SFL), language has variations according to the context of situation and the context of culture.

From this idea, this course design uses the concept of genre and is based on different types of texts with different kinds of functions. The course design uses biographies, classification, process, and mechanism texts that are analysed and reconstructed in terms of specific activities suitable for each text type. These activities are called DARTS (Directed Activities Related to Text) which are designed to gain knowledge of the structure of the text and which 
are really helpful in the study of academic content texts (Lunzer, Gardner, Davies, \& Greene, 1984).

\section{Goals and Objectives}

The goals are defined in terms of target, learning and humanistic goals. This is an important part of the project since it constitutes the outline for the design of the whole course (see Table 2).

Table 2. Goals and Objectives of the Pedagogical Proposal

\begin{tabular}{||l|l||}
\hline \multicolumn{1}{|c||}{ Goals } & \multicolumn{1}{c||}{$\begin{array}{c}\text { Objectives } \\
\text { Students should be able to: }\end{array}$} \\
\hline Target: Development of reading skill & $\begin{array}{l}\text { Comprehend texts related to ninth grade } \\
\text { science curriculum. }\end{array}$ \\
\hline $\begin{array}{l}\text { Learning: Encouragement of reading } \\
\text { strategies }\end{array}$ & Make use of different reading strategies. \\
\hline $\begin{array}{l}\text { Human: Encouragement of respect and } \\
\text { acceptance of others' opinions }\end{array}$ & $\begin{array}{l}\text { Work together, respect, and accept their } \\
\text { classmates' opinions. }\end{array}$ \\
\hline
\end{tabular}

\section{Syllabus Focus}

I chose content-based approach (CBA) as the most appropriate syllabus focus of this design. Among the reasons for this selection are the use of academic and authentic readings as one of the main sources of input as well as the flexibility and adaptability to any kind of context. The reading texts were taken from science books used in bilingual schools and from different websites. Accordingly, this content-based course was theme-based because it encourages the use and teaching of content without neglecting the language which is its most important objective. Theme-based approach refers to a course that offers a strong language projection and gives flexibility and autonomy in the selection of the content (Dueñas, 2004).

On the other hand, matrix syllabus structure was the most suitable for the design. The matrix shows the connection that exists among all the key elements of this course such as the topics, the genres and texts, the reading strategies, and the linguistic structures. The topics and the units were organized in terms of genres. In the first unit students read four biographies about the fathers of taxonomy: The First Taxonomist (Andrea Cesalpino), A Man of Science (Charles Darwin), The Father of Classification (Carl Linnaeus), and A Religious Scientist 
The Design of a Theme-Based and Genre-Oriented Strategic Reading Course to Improve Students' Reading Comprehension Skills at a Public School in Colombia

(John Ray). In the second unit, students read four descriptive texts of classification: Invertebrates, Arthropods, Vertebrates, and Mammals.

\section{Course Methodology}

The methodology was basically based on DARTS (Lunzer et al., 1984). These activities were designed according to the text genre and were focused on two main aspects: analysis and reconstruction of the text. For the analysis of the reading texts students mainly did the following activities: labeling, text marking, tabulating, and summarizing. For the reconstruction of the text, students did sequencing and table completion.

Labeling. With this activity students recognized the macro-structure of the text and were able to tag or label the parts of the text according to its genre. Thus, students were able to recognize the regular patterns that characterized the texts that belong to the same type.

Text marking. Through this activity, students identified specific information in the text. They focused on dates, characters, attributes, and so on; students recognized remarkable information that was relevant for their comprehension.

Tabulation. With this activity, students designed charts that helped them organize the information they found in the text. Its main purpose was to categorize relevant information.

Summarizing. The summarizing activity let students synthesize the information they found in the text and enabled them to demonstrate that there was real comprehension of the content.

Sequencing. Since the intention of this activity was to reconstruct the text, students were able to organize the sequence of the text (narration, process, etc.). In the case of narrative texts or biographies, students organized the text in chronological order (see Appendix 3).

Table completion. This activity helped students reconstruct the text by completing a table provided by the teacher. Unlike the tabulating activity, in this activity students were given the chart after the reading of the text.

Furthermore, students carried out a series of interactive reading activities such as peer reading and jigsaw reading. These activities tackled the sociocultural theory which is a fundamental support of this project.

Peer reading. For this activity, students were sitting in pairs but read individually. While reading, they shared their thoughts and made comments on important aspects of the texts. If any misunderstanding or disagreement arose, they discussed it in order to reach agood level of comprehension.

Jigsaw reading. For jigsaw reading students worked in pairs or groups. Each of the students had part of the information contained in the whole text. They read this specific part 
and then gave this information to their peers or group, who in turn provided them with the missing information.

\section{Results From Piloting}

Four hours of Unit 1 of this course design were piloted. This represents the application of two of the three lesson plans prepared for this unit. The purpose of this piloting was to analyze and evaluate the implementation of this proposal and its effectiveness in the improvement of the target students' reading comprehension. The instruments that were designed to measure the effectiveness of the proposal were a checklist for students, a self-evaluation form, and an observation guideline.

The checklist for students consisted of a Likert Scale that was applied in pairs and at the end of each lesson. Its purpose was to encourage students' tolerance and respect when expressing their opinion, one of the humanistic goals of this course design. Regarding the results obtained from this instrument, students stated that, in spite of the fact that the reading texts were in English, it was easier for them to comprehend thanks to the strategies proposed and the role of the teacher as a mediator between them and the content of the texts. These are some remarks students wrote in the observation part of the checklist - the excerpts have been translated from Spanish:

The activities were greatly appropriate and helped me comprehend the text.

The texts were very important and this motivated me to try to understand; I could also learn new things.

Meaning deduction strategies helped me comprehend more.

I think I can implement all the strategies I learned in future readings.

With regard to the texts, they were about the same topics students were studying in their regular content classes in Spanish; this was a reason why many students stated they were interesting and relevant for their regular classes in ninth grade, and this aspect also facilitated their comprehension. Concerning the activities proposed by the teacher, these were oriented to help students improve their reading comprehension. After the application of the instrument, students stated the activities were meaningful and helped them with the comprehension of the text, as well as to access the content of the reading passage.

The activities were basically about the use of reading strategies and DARTS. According to students, the most useful activities for their comprehension were the identifications of general ideas and specific information. For students, these two activities helped them achieve the goals of the class in terms of language and content. Other activities that students considered really useful for their comprehension were the deduction of meaning and the organization of the information through the connectors of sequence and a flow chart. With 
The Design of a Theme-Based and Genre-Oriented Strategic Reading Course to Improve Students' Reading Comprehension Skills at a Public School in Colombia

the deduction activity, students confirmed it was not necessary to know every single word of the text in order to understand it. Students realized that the context and the words surrounding the unknown word are important tools that help the reader deduce the meaning.

On the other hand, the observation guideline was given to a colleague for getting her opinion on the development of the class and the effectiveness of the methodology and activities I proposed. The tool revealed low achievers were not participating and only students with high levels were interested in the class. As an outcome of this suggestion, students were organized in a different way for the application of the second lesson plan. Two low achievers were sitting next to a more capable peer who encouraged them to participate and who assisted and supported them while reading. Therefore, there was more participation of low achievers in the second class because they could interact with their classmates first and then felt more confident to answer the teacher.

In turn, the self-reflection helped me get a better insight of what I believed regarding the development of the class and the effectiveness of my proposal. First of all, I could achieve the purpose of the class. I think students could both learn about the topics and understand the texts proposed. Regarding the strategies taught, students did not have any problem, basically because the information was clearly provided. I could see students understood the content of the reading texts because they answered the questions I asked them as they were developing the activity. For the second lesson plan, students were more used to the methodology implemented, so they could follow the thread of the class much better. The structure of the text was also familiar to them. For the second reading text students already knew how to identify the parts of a biography which gave them a plus when reading and comprehending the general idea.

Likewise, the activities were appropriate for students because they clearly understood what they were required to do and also these activities facilitated their comprehension of the text. Furthermore, I consider the activities were challenging for students and were also doable so students felt they were gaining confidence and learning new content and language.

On the other hand, I could reinforce the weaknesses students had had before by identifying some weak points in which they failed the first class regarding vocabulary; so I tried to tackle this aspect by providing more activities related to getting the meaning of words. Concerning things to be improved, I would provide students beforehand with the target vocabulary and do previous activities with the key vocabulary so that they will get a better idea of words. In general terms students were satisfied with the proposal because they considered the activities to be organized in a good sequence that progressively helped them with the comprehension of the text. In addition, students believed the class was relevant for the understanding of authentic texts in English which they were not accustomed to read. 


\section{Conclusions and Further Research}

The idea of this intervention was to understand if it was possible to design a course based on genre and content in order to improve the reading competence of students in public schools. Besides, it was also a purpose of this project to provide students with strategies which help them access academic texts in English despite their being low achievers. After the implementation of the proposal, it can be stated that students from public schools can improve their reading comprehension if they are provided with meaningful texts and with the appropriate reading strategies. The incorporation and integration of content-based instruction and genre approach were pivotal and innovative for students, who recognized that this course made them feel more comfortable when reading in English and helped them enhance their reading skills.

There are several practical applications for the results of this study. I strongly recommend the use of adequate texts that suit the necessities and likes of the students. It is important to have an appropriate selection of texts that represent for students both a challenge, because they are learning a new language, and also academic development, because they are acquiring new knowledge through the foreign language. Likewise, future interventions should use texts with topics that are familiar to the students, so they will have a notable support and background to access the reading texts and to comprehend them.

Moreover, further interventions should take into account the use of specific genres. It is possible to have students — and even more so struggling students — comprehend academic texts if the activities provided by the teacher correspond to and suit a specific kind of genre. When students get to understand the structure of a text and are able to recognize its outline, it will be easier for them to decide the kind of strategy to be used in order to achieve better comprehension.

On the other hand, the development of this project helped me understand the importance of previously analyzing the target context and all the characteristics of the target group. Once I had enough information about the class, I could design a course with suitable texts and activities for my students to reach the goals proposed. After analyzing the results of the intervention and evaluating its appropriateness and effectiveness, I could confirm that the target students could improve their performance in both the institutional and the external tests, especially the SABER where they demonstrated a significant achievement.

About the experience I gained with this project, I had the opportunity to go to the classroom and see it from different perspectives. This time, I approached the classroom as a researcher without leaving behind my role as a teacher. Because of this, I could find students were having reading comprehension problems; therefore, I decided to take action. It is relevant to teach reading strategies in order to improve reading comprehension of the students from the lower to the higher grades in primary and high school. To get this, students should be guided to increase their reading habits. One way to do this is by having them read not only in English but 
The Design of a Theme-Based and Genre-Oriented Strategic Reading Course to Improve Students' Reading Comprehension Skills at a Public School in Colombia

mainly in their native language since most of the problems faced by students regarding comprehension originate because they are not competent in their mother tongue.

\section{References}

Alderson, J. C. (2000). Assessing reading. Cambridge, UK: Cambridge University Press. http://dx. doi.org/10.1017/CBO9780511732935.

Bakhtin, M. M. (1973). Problems of Dostoevsky's poetics (R. W. Rotsel, Trans.). Ann Arbor, MI: Ardis.

Brinton, D. M., Snow, M. A., \& Wesche, M. (1989). Content-based second language instruction. Boston, MA: Heinle \& Heinle Publishers.

Chamot, A. U. (1987). The learning strategies of ESL students. In A. Wenden \& J. Rubin (Eds.), Learner strategies in language learning (pp. 71-83). Englewood Cliffs, NJ: Prentice/Hall International.

Derewianka, B. (1991). Exploring how texts work. Newtown, AU: Primary English teaching association.

Dueñas, M. (2004). The whats, whys, hows, and whos of content-based instruction in second/foreign language education. International journals of English studies, 4(1), 73-96.

Hyland, K. (2007). Genre pedagogy: Language, literacy and L2 writing instruction. Journal of second language writing, 16(3), 148-164. http://dx.doi.org/10.1016/j.jslw.2007.07.005.

Johnson, M. (2003). A philosophy of second language acquisition. Binghamton, NY: Yale University Press.

Lee, P. Y. (2010). The content-based reading approaches (COBRA) model in the ELL and LD classroom. Retrieved from ERIC database. (ED512529)

Lewis, C. (1982). Using the "thinking aloud" method in cognitive interface design. Yorktown Heights, NY: IBM Thomas J. Watson Research Center.

Lunzer, E., Gardner, K., Davies, F., \& Greene, T. (1984). Learning from the written word. Liverpool, UK: Oliver and Boyd.

Oxford, R. L. (1989). Language learning strategies: What every teacher should know. Boston, MA: Newbury House.

Preszler, J. (2005). On target: Reading strategies to guide learning. San Diego, CA: Black Hills Special Services Cooperative.

Vygotsky, L. S. (1978). Mind in society: The development of higher psychological processes. Cambridge, MA: Harvard University Press.

Wallace, C. (1992). Reading. Oxford, UK: Oxford University Press.

\section{The Author}

Fabián Padilla De La Cerda is an English teacher at a public school and at the languages department of Universidad del Norte in Barranquilla, Colombia. He has twelve years of experience in education and holds a BA in Foreign Languages from Universidad del Atlántico (Colombia) and an MA in the teaching of English from Universidad del Norte. 


\section{Appendix 1: Reading Proficiency Test}

1. The diet of the panda bear is represented by: (Literal)
a. Fish
b. Penguins
c. Bamboo

2. The expression "They are the smallest birds that exist" in the third paragraph means that: (Literal)
a. There are other birds that are bigger than humming birds.
b. There are no other birds that are smaller than humming birds.
c. Only some humming birds are small.

3. The word "cubs" in the first paragraph refers to: (Literal)
a. Adult bears
b. Female bears
c. Baby bears

4. A synonym for the word "hibernate" in the first paragraph is: (Literal)
a. Sleep during the winter
b. Eat during the winter
c. Hunt during the winter

5. In the first paragraph the word "Although" is used to: (Inferential)
a. Introduce a new idea
b. Introduce an example
c. Offer a contrast to the main sentence

6. The text talks about: (Inferential)
a. The behavior of bears, frogs, and humming birds
b. The characteristics of bears, frogs, and humming birds
c. A description of the bears', frogs', toads', and humming birds' habitat.

7. Based on the text, it can be said that (Inferential)
a. All bears share the same characteristics.
b. Bears have remarkable differences. 
The Design of a Theme-Based and Genre-Oriented Strategic Reading Course to Improve Students' Reading Comprehension Skills at a Public School in Colombia

c. Bears live in the same environment.

8. The intention of the text is to: (Inferential)

a. Contrast the way of living of the three animals

b. Describe the main attributes of the three animals

c. Explain the life cycle of the three animals

9. According to the text a frog and a toad: (Inferential)
a. Are the same
b. Look very similar
c. Eat the same food

10. Which of the animals live in both water and land? (Literal)
a. Humming birds
b. Bears
c. Frogs and toads 


\section{Appendix 2: Think Aloud Protocol Questionnaire}

1. What was the first thing you did when you started to read the text in order to try to understand?

2. Do you have a global idea of what the text is about? If so, how did you get this?

3. What was the first thing you did when you read the title of the text? How did the title help you?

4. What are you doing now when you start to read the text?

5. What do you do to find out the gist?

6. Which parts of are the most difficult?

7. What do you do when you do not understand a word? How do you manage to understand it?

8. What has helped you most to understand this reading?

9. If I ask you to study the unknown words, how would you do it?

\section{During the reading}

1. Now that you are in front of the text, what are you doing?

2. What was the most difficult question? Why do you think it was difficult?

3. Now that you are in the middle of the text, what is the first thing that comes to your mind?

4. Before finishing reading, what were you doing mentally?

5. Now that you have completed the text, what mental processes are you performing?

6. Did you read this text as you normally do it or did you use a special technique?

7. What do you think is the best way to read a text?

8. What helps you understand a text better? 
The Design of a Theme-Based and Genre-Oriented Strategic Reading Course to Improve Students' Reading Comprehension Skills at a Public School in Colombia

\section{Appendix 3: Sequenced Flow Chart}

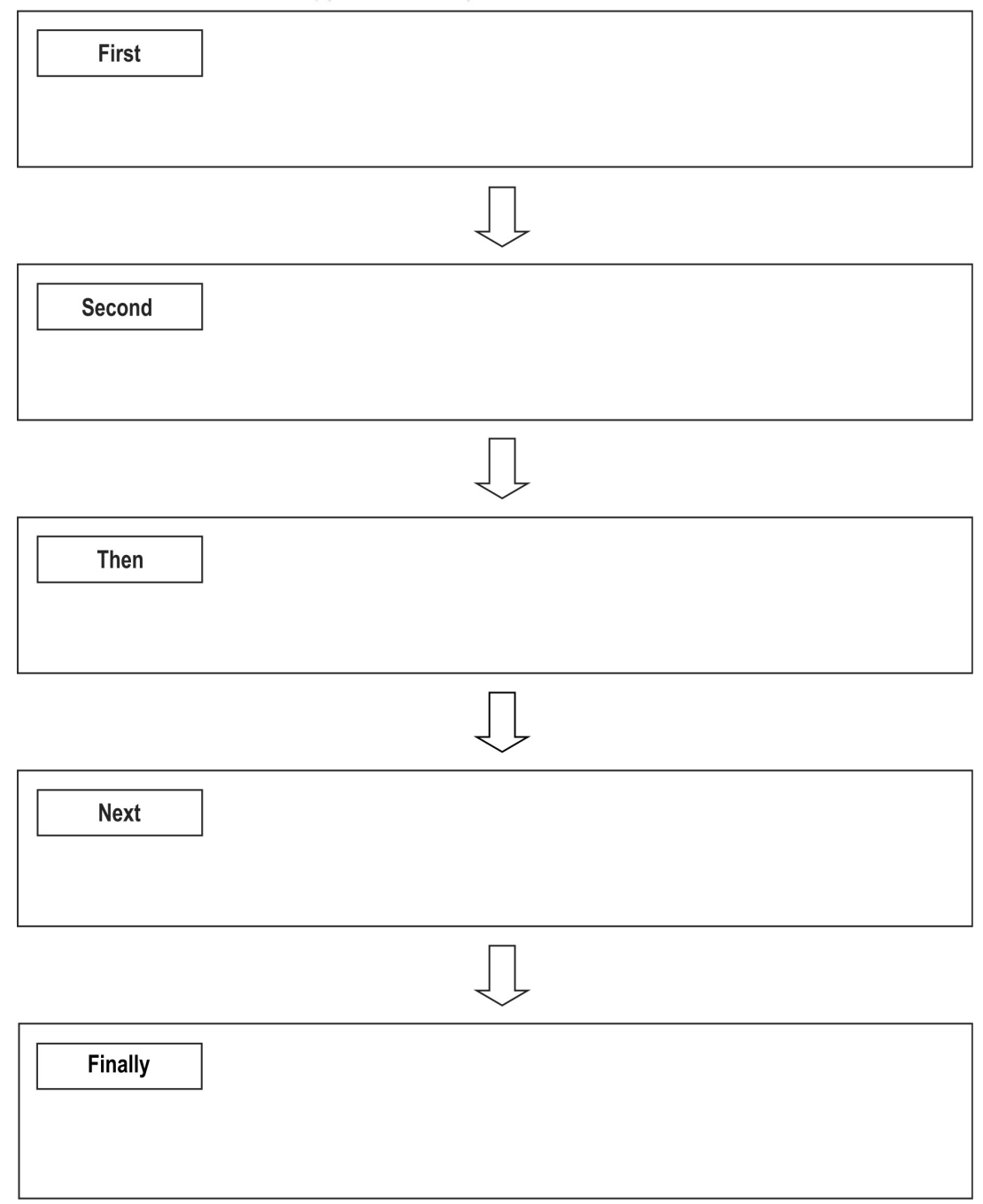

